\title{
Linkage disequilibrium and recombination make a telomeric site for the Huntington's disease gene unlikely
}

\author{
Lilias Barron, Ann Curtis, A E Shrimpton, Susan Holloway, Heather May, Russell G Snell, \\ D J H Brock
}

\begin{abstract}
In a Scottish family in which Huntington's disease (HD) was segregating, recombination was observed between the D4S115/S111 and D4S43/S95 loci, with the HD gene associated with the more proximal D4S43/S95 locus. Analysis of linkage disequilibrium in Scottish families showed significant non-random association between the HD gene and alleles at the D4S95 and D4S98 loci. This adds to previous evidence that the HD locus is not sited at the telomere of chromosome 4.
\end{abstract}

Although the Huntington's disease. (HD) locus was localised to the short arm of chromosome 4 in $1983,{ }^{1}$ there is still considerable uncertainty about its precise location. Several recombinants have suggested a telomeric site for the mutation, ${ }^{2-5}$ which led to efforts to clone the $4 \mathrm{p}$ telomere. ${ }^{67}$ Other recombinants point to a more proximal location,,$^{58}$ and this is supported by linkage disequilibrium data. ${ }^{910}$

In the course of providing presymptomatic testing for HD in Scottish families, we encountered a recombinant adding to the evidence for a nontelomeric location for the HD gene. A review of allele frequencies at marker loci on $\mathrm{HD}$ and normal chromosomes, carried out in an ethnically homogeneous Scottish population, confirmed ${ }^{9}{ }^{10}$ significant

Human Genetics Unit, University of Edinburgh, Western General Hospital, Edinburgh EH4 2XU.

L Barron, A Curtis, A E Shrimpton, S Holloway, D J H Brock

Duncan Guthrie Institute of Medical Genetics, Yorkhill, Glasgow.

H May

Institute of Medical Genetics, University of Wales College of Medicine, Heath Park, Cardiff CF4 4XN.

R G Snell

Correspondence to Professor Brock.

Received for publication 14 January 1991

Accepted for publication 25 February 1991. linkage disequilibrium at the more proximal $D 4 S 95$ and D4S98 loci.

Materials and methods

A total of 82 unrelated families, all of Scottish origin and referred to Edinburgh for presymptomatic or prenatal exclusion testing, was used as the source of data for HD chromosomes. For controls the alleles in spouses and those segregating with the non-HD chromosomes were used. Linkage disequilibrium was analysed by $\chi^{2}$ test with Yates's correction.

DNA polymorphisms examined were $674 \mathrm{E}-\mathrm{D} / \mathrm{TaqI}$ and 674E-D/MboI (D4S95), ${ }^{11}$ XP500/MspI and KP1.65/BgII (D4S43), ${ }^{12}$ 731/SacI (D4S98), 157.9/PstI $(D 4 S 111),{ }^{12}$ and $252 \cdot 3 / P s t I(D 4 S 115){ }^{12} \mathrm{~A}$ further unpublished system, R10/BamHI, about $30 \mathrm{~kb}$ distal to $D 4 S 98$, was also used.

\section{Results}

In the family shown in the figure the HD gene is segregating with the extended haplotype (telomere)4-C-1-3-D-1-2·3-1 2-(centromere), since this chromosome is found in five affected subjects in three generations (II.4, II.5, III.5, III.6, and IV.5). Only one other affected person was available for typing in this family, IV.3, who had a recombinant HD chromosome, in which the HD gene is associated with the more proximal markers. The haplotypes in this subject's dead affected father (III.3) can be reconstructed from sibs of IV.3 and from other members of the extended family. This suggests that the most likely event was a crossover in a paternal meiosis (III.3) between markers 157.9/PstI (D4S111) and KP1 65/BglI (D4S43), with the HD gene proximal to D4S111. Polymorphisms at the intervening D4S98 locus were not informative. Because one of the sibs in generation IV is unaffected at the age of 30 but carries an HD chromosome, individual genders are not shown.

Only one probable haplotype is shown for the dead woman III.4. It has been reconstructed from haplotypes found in her unaffected children, IV 22 and IV $\cdot 4$. However, if the other haplotype in III 4 were 


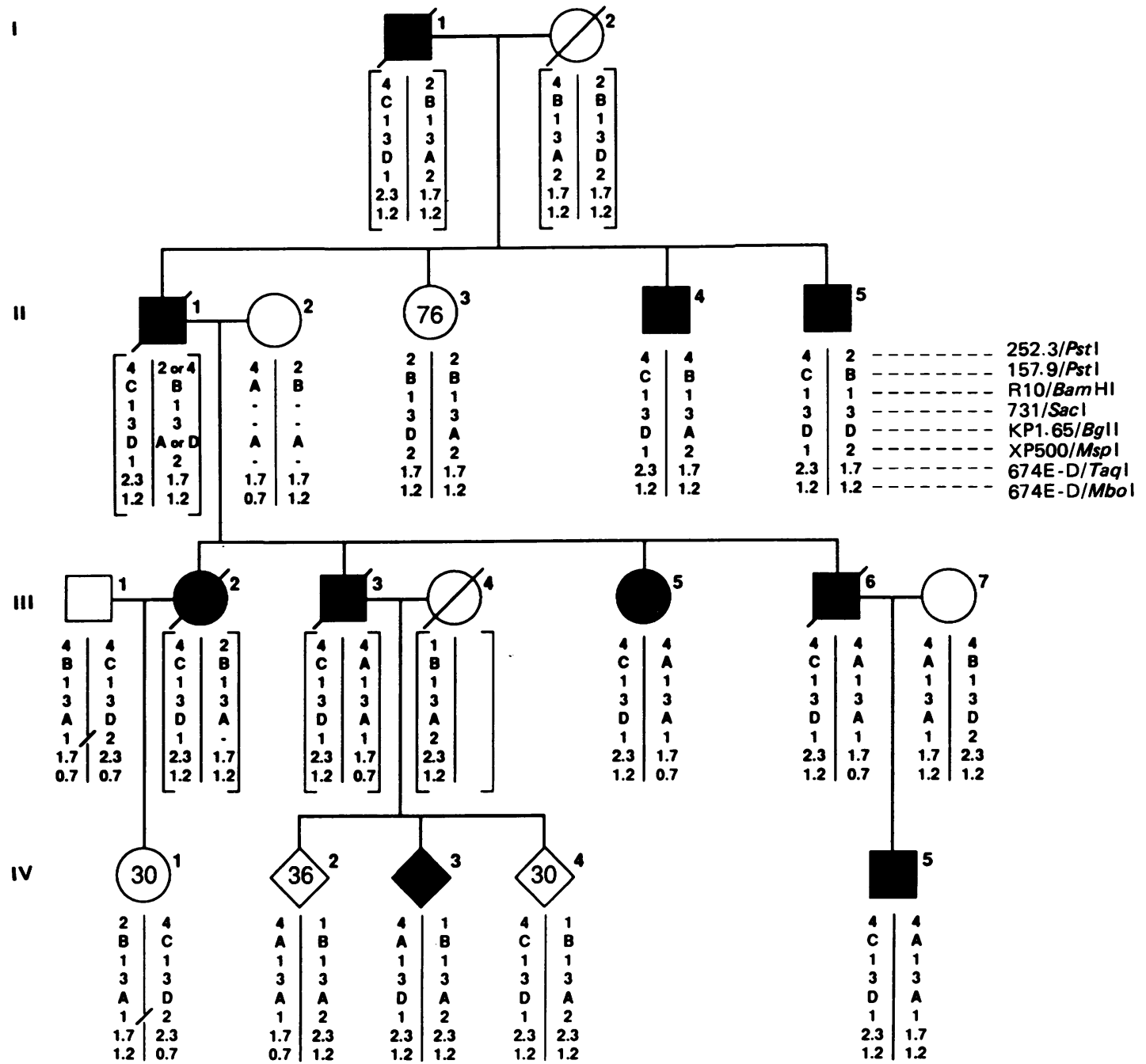

Family in which HD was segregating. Affected subjects are shaded. Ages of relevant unaffected persons are shown in pedigree symbols. Inferred haplotypes are in brackets. Recombination was observed in IV 3.

(telomere)-1-B-1-3-D-2-2·3-1-2-(centromere), then the $\mathrm{A}$ and $\mathrm{D}$ alleles at the $D 4 S 43$ locus $(\mathrm{KP1} \cdot 65 / \mathrm{Bg}$ II) in IV 3 could be on opposite chromosomes to those shown proximal to $D 4 S 43$. However, although this possibility cannot be ruled out, it demands the existence of a haplotype in III 4 for which there is no independent evidence.

Linkage disequilibrium data for polymorphisms at $D 4 S 111, D 4 S 98$, and $D 4 S 95$ are shown in the table. We have excluded results from three other systems in routine use in this laboratory, $252 \cdot 3 / P s t \mathrm{I}, \mathrm{KP1} \cdot 65 / \mathrm{BgII}$, and XP500/MspI, since they detect multiple alleles which are difficult to compare between different Southern blots. In earlier work with seven polymorphisms at the D4S10 locus, we were unable to find any significant linkage disequilibrium (data not shown).

There is significant non-random association between the HD gene and alleles detected by 674E-D/MboI, 674E-D/TaqI, and 731/SacI (table). We have also included data from 157.9/PstI (D4S111) which, although detecting five alleles, is comparatively easy to score, and where the distribution of alleles on HD and normal chromosomes was very similar. 
Allele frequencies and percentages on $H D$ and normal $(N)$ chromosomes.

\begin{tabular}{|c|c|c|c|c|c|}
\hline $\begin{array}{l}\text { Locus } \\
\text { (probe/enzyme) }\end{array}$ & Allele & $\begin{array}{c}\text { HD } \\
\text { No (\%) }\end{array}$ & $\frac{N}{\text { No }(\%)}$ & $\begin{array}{l}\chi^{2} \\
\text { (with Yates's } \\
\text { correction) }\end{array}$ & $\begin{array}{l}\text { Relative } \\
\text { risk* }\end{array}$ \\
\hline $\begin{array}{l}D 4595 \\
\quad(674 \mathrm{E}-\mathrm{D} / \mathrm{MboI})\end{array}$ & $\begin{array}{l}1 \cdot 2 \\
0 \cdot 7\end{array}$ & $\begin{array}{c}48(91) \\
5(9)\end{array}$ & $\begin{array}{r}186(67) \\
92(33)\end{array}$ & $10.913 t$ & $4 \cdot 75$ \\
\hline $\begin{array}{l}D 4 S 95 \\
\quad(674 \mathrm{E}-\mathrm{D} / \mathrm{TaqI})\end{array}$ & $\begin{array}{l}2 \cdot 3 \\
1 \cdot 7\end{array}$ & $\begin{array}{l}24(51) \\
23(49)\end{array}$ & $\begin{array}{r}96(34) \\
183(66)\end{array}$ & $4 \cdot 108 \ddagger$ & 1.99 \\
\hline $\begin{array}{l}\text { D4S98 } \\
\quad(731 / \mathrm{SacI})\end{array}$ & $\begin{array}{l}2 \\
3\end{array}$ & $\begin{array}{l}15(27) \\
41(73)\end{array}$ & $\begin{array}{r}29(11) \\
231(89)\end{array}$ & $8 \cdot 135 t$ & $2 \cdot 91$ \\
\hline $\begin{array}{l}D 4 S 111 \\
\quad\left(157 \cdot 9 / P_{s t} \mathrm{I}\right)\end{array}$ & $\begin{array}{l}\alpha \\
\mathbf{A} \\
\mathbf{B} \\
\mathbf{C} \\
\mathbf{D}\end{array}$ & $\begin{array}{c}1(3) \\
12(32) \\
20(54) \\
4(11) \\
0\end{array}$ & $\left.\begin{array}{c}1(0.5) \\
52(28) \\
103(56) \\
28(15) \\
1(0.5)\end{array}\right\}$ & 0.613 & \\
\hline
\end{tabular}

${ }^{*}$ Relative risks for alleles $1 \cdot 2,2 \cdot 3$, and 2 being in coupling with the $\mathrm{HD}$ gene, respectively. tp<0.01.

$\neq \mathrm{p}<0.05$.

\section{Discussion}

Bucan et $\mathrm{al}^{13}$ have constructed a physical map of the chromosome region $4 \mathrm{pl} 16.3$ and ordered DNA markers within three clusters. Those referred to in this paper are: segment I: centromere....D4S10; segment II: D4S95-D4S43-D4S98; segment III: D4S115-D4S111-D4S90 .....telomere. A majority of recombinants between the HD gene and informative markers has placed the HD locus in segment III, ${ }^{2-5}$ with several recombinants indicating that it is telomeric to the distal locus $D 4 S 90 .{ }^{34}$ However, two recombinants indicated a location proximal to $D 4 S 115,{ }^{58}$ suggesting that the HD locus may be in segment II. In the family analysed in this study a recombinant event was observed in which the HD gene appeared to be segregating with segment II markers.

This finding is supported by linkage disequilibrium data. In two earlier studies, ${ }^{10} 11$ no evidence was found for non-random allele distribution on HD and normal chromosomes using DNA polymorphisms in segments I and III. However, significant linkage disequilibrium was observed at the $D 4 S 95$ and $D 4 S 98$ loci in segment II. Our results confirm these findings. No disequilibrium was seen at the $D 4 S 10$ locus (data not shown) or at the D4S111 locus in segment III. However, both polymorphisms examined at the $D 4 S 95$ locus and one polymorphism examined at the D4S98 locus showed significantly different allele distributions between HD and normal chromosomes. Where it is possible to make direct comparisons (674E-D/MboI at D4S95 and 731/SacI at D4S98), the same allele is preferentially associated with the HD gene in all three studies. The main difference between this and the two previous studies ${ }^{10} 11$ is that $w$ ? found significant disequilibrium with the 674E-D/TaqI polymorphism $(p<0.05)$ on HD and normal chromosomes.
We thank Drs J F Gusella and J J Wasmuth for gifts of the probes, and colleagues in Glasgow for preparing DNA samples. This work was supported by a gift from the Ludovici Bequest to the University of Edinburgh.

1 Gusella JF, Wexler NS, Conneally PM, et al. A polymorphic DNA marker genetically linked to Huntington's disease. Nature 1983;306:234-9.

2 Whaley WL, Michiels F, MacDonald ME, et al. Mapping of D4S95/S114/S113 confines the Huntington's defect to a reduced region at the telomere of chromosome 4. Nucleic Acids Res 1988;16:11769-80.

3 Robbins C, Theilmann J, Youngman S, et al. Evidence from family studies that the gene causing Huntington disease is telomeric to D4S95 and D4S90. Am f Hum Genet 1989;44: $422-5$.

4 Youngman S, Sarfarazi M, Bucan M, et al. A new DNA marker (D4S90) is located terminally on the short arm of chromosome 4, close to the Huntington disease gene. Genomics 1989;5: 802-9.

5 McDonald ME, Haines JL, Zimmer M, et al. Recombination events suggest potential sites for the Huntington's disease gene. Neuron 1990;3:183-90.

6 Doggett NA, Cheng JF, Smith CL, Cantor CR. The Huntington disease locus is most likely within 325 kilobases of the chromosome 4p telomere. Proc Natl Acad Sci USA 1990;86: $10011-4$.

7 Pritchard C, Casher D, Bull L, Cox DR, Myers RM. A cloned DNA segment from the telomeric region of human chromosome $4 \mathrm{p}$ is not detectably rearranged in Huntington disease patients. Proc Natl Acad Sci USA 1990;87:7309-13.

8 Bates GP, MacDonald ME, Baxendale S, et al. A yeast artificial chromosome telomere clone spanning a possible location of the Huntington disease gene. Am ₹ Hum Genet 1990;46:762-75.

9 Snell RG, Lazarou LP, Youngman S, et al. Linkage disequilibrium in Huntington's disease: an improved localisation for the gene. f Med Genet 1989;26:673-5.

10 Theilmann J, Kanani S, Strang R, et al. Non-random association between alleles at D4S95 and D4S98 and the Huntington's disease gene. F Med Genet 1989;26:676-81.

11 Wasmuth JJ, Hewitt J, Smith B, et al. A highly polymorphic locus very tightly linked to the Huntington's disease gene. Nature 1988;332:734-6.

12 McDonald ME, Cheng SV, Zimmer $M$, et al. Clustering of multiallele DNA markers near the Huntington's disease gene. $\mathcal{f}$ Clin Invest 1989;84:1013-6.

13 Bucan M, Zimmer M, Whaley WL, et al. Physical maps of 4p16.3, the area expected to contain the Huntington disease mutation. Genomics 1990;6:1-15. 